\title{
Experiment Study of Catalysed Lignocellulosic Biomass Thermoelectric Concrete with Active Solution
}

\author{
Hoong-Pin Lee*, Kar-Loke Teow, Wen-Zhang Lee, Nurharniza Abdul Rahman \\ School of Civil Engineering, Faculty of Engineering and Quantity Surveying, INTI International University, Malaysia \\ Received May 23, 2021; Revised October 19, 2021; Accepted November 17, 2021
}

\section{Cite This Paper in the following Citation Styles}

(a): [1] Hoong-Pin Lee, Kar-Loke Teow, Wen-Zhang Lee, Nurharniza Abdul Rahman, "Experiment Study of Catalysed Lignocellulosic Biomass Thermoelectric Concrete with Active Solution," Civil Engineering and Architecture, Vol. 10, No. 1, pp. 366-375, 2022. DOI: 10.13189/cea.2022.100131.

(b): Hoong-Pin Lee, Kar-Loke Teow, Wen-Zhang Lee, Nurharniza Abdul Rahman (2022). Experiment Study of Catalysed Lignocellulosic Biomass Thermoelectric Concrete with Active Solution. Civil Engineering and Architecture, 10(1), 366-375. DOI: 10.13189/cea.2022.100131.

Copyright $\mathrm{C} 2022$ by authors, all rights reserved. Authors agree that this article remains permanently open access under the terms of the Creative Commons Attribution License 4.0 International License

\begin{abstract}
Emission of $\mathrm{CO}_{2}$ becomes one of the global challenges and catalyzed lignocellulosic biomass thermoelectric concrete $(\mathrm{CBC})$ is a new source of energy which helps to encounter this challenge. $\mathrm{CBC}$ is an advance class of concrete, which has proven to be able to generate voltages throughout thermal change, but several drawbacks were reported such as low voltage and insufficient compressive strength to meet construction industry needs. This study intends to investigate the incorporation of active solution like alkali/acidic solution as activation booster, palm oil fuel ash (POFA) as partial cement replacement and catalyst for charges extraction, under thermal changes. Active solutions used in this study were Sodium Hydroxide, Iron(III) Sulfate, and Copper(II) Sulfate. Specimens with dimension of $50 \times 50 \times 20 \mathrm{~mm}$ and $150 \times 150 \times 150 \mathrm{~mm}$ were prepared and cured accordingly; then tested its conductivity with temperature ranged from $0^{\circ} \mathrm{C}$ to $100^{\circ} \mathrm{C}$; and uniaxial compressive strength test, respectively. The experiment has proven that incorporation of active solution in CBC mix is able to enhance both voltage supply and compressive strength by average $249.73 \%$ and $41.64 \%$ (with active solution $\mathrm{Fe}_{2}\left(\mathrm{SO}_{4}\right)_{3}$ ), respectively. With a complete circuit, it can be noticed that specimen's voltage density is directly proportional to exposed temperature, from $38.35 \mathrm{~V} / \mathrm{m}^{2}$ at $0^{\circ} \mathrm{C}$ to $129.67 \mathrm{~V} / \mathrm{m}^{2}$ at $100{ }^{\circ} \mathrm{C}$. The study has proven that $\mathrm{CBC}$ with addition of active solution is able to enhance the matured compressive strength and at the same time, carrying voltage when a complete circuit is applied. With this, the application of $\mathrm{CBC}$ in construction industry has been increased to structural application for
\end{abstract}

alternative renewable energy source.

Keywords Catalysed Biomass Concrete, Renewable Energy, Novel Energy Source, Sustainability, Advance Concrete Materials

\section{Introduction}

Rapid growth in economic and living standards has leaded to massive consumption of fossil fuels in order to render for the huge energy demand. Fossil fuels such as coal, oil and natural gas are depleting days by days. This has caused problems like shortage of fossil fuels, climate changes, and environmental pollution [1]. Comparing to other sectors, concrete industry and buildings are the largest energy consumers worldwide, accounting for about $40 \%$ of energy consumption as reported by the United Nations Environment Programme [2]-[5]. Thus, sustainable and environmentally friendly solution for alternative renewable energy source must be developed so to resolve current energy situation and prepare us for the future.

Lignocellulosic biomass (such as cellulose, poplar, lignin, switch grass, and the list goes on) is a natural alternative renewable resource that can be obtained in large quantities around the world. It consists of organic matter such as living or dead organisms and the by-products after certain production processes of those 
organisms. According to Bajpai [6], typical biomass components include celluloses, hemicelluloses, lignin, starch, protein, pectin and other organic and inorganic components. Besides, biomass is able to be produced from different sectors of industry that are capable to use as energy sources such as animal residues, industrial residues, agricultural residues, forestry residues, municipal solid waste and sewage [7]. All the biomass is able to store solar energy in their cells through photosynthesis and convert it into chemical energy as a main energy resource in the form of carbohydrates to survive. This type of chemical energy is able to be used as a power to generate electricity when the biomass undergoes a high temperature of combustion. Government of Malaysia recognizes biomass as a high potential renewable energy source and there are numerous biomass power stations in Malaysia. Commercially, it needs high temperature combustion and gasification together with a steam or gas turbine to generate electricity, which in return yields another environmental pollution. Many researches [8]-[16] have started to look for alternative way to extract electricity from biomass with more environmental friendly way so to cater with the drawbacks. Hence, there is a need to discover alternative renewable energy that brings positive benefit to the environment, in line with National Renewable Energy Policy: Achieving 20\% renewable energy capacity mix by 2025.

Scientists and engineers are searching innovative substances with cementitious properties that are able to replace cement and at the same time, fulfil the green building requirements. There are researchers [3], [17], [26], [18]-[25] proved that concrete using lignocellulosic biomass results in higher compression strength and is able to reduce the emission of $\mathrm{CO}_{2}$ during production. Furthermore, the durability, chemical resistance properties, low heat development and other mechanical properties of such concrete are higher than the concrete using just ordinary Portland cement only. Lignocellulosic biomass like palm oil fuel ash, sugar cane bagasse ask, rice husk ash, wood saw ash, bamboo leaf ash, maize ash, etc. possesses cementitious properties and is suitable to be used in concrete mix [27]. With the outbreak of the research, part of the cement content is able to replace with recyclable materials and results in satisfy performance of concrete. However, the potential of biomass as renewable resource in concrete is yet fully discovered. Biomass, eventually has been greatly proven by researches on its capability in enhancing concrete's properties, at the same time is also believed that can be catalyzed to generate electricity under certain exposing criteria. Incorporation of catalyzed biomass and concrete constituents can re-character public impression to concrete where it no longer only gives strength and integrity to building structure, but generates electricity under thermal exposure.

Researches on electrified lignocellulosic biomass [8][10], [12]-[16], [28], [29] have been conducted and a low temperature, clean, portable, carbon neutral, alternative electricity production that is suitable for a variety of applications is invented. It is classified into indirect biomass fuel cells and direct biomass fuel cells, and able to generate electricity with power density of 0.72 milliwatts per square centimeter, and is near to the results of the best microbial fuel cells. With addition of activated catalyst and exposure to heat or solar energy, lignocellulosic biomass with external circuit is able to utilize surrounding oxygen particles to generate electricity. Lignocellulosic biomass is generally not efficient to be directly used as any conductor in any conventional way. It needs to be mediated with catalytic in order to convert biomass to electricity under solar or thermal. Variety researches are conducted for fuel cell application, and there is no literature for the application of biomass in concrete to generate electricity charges, which is believed to be one of the breakthrough research contributions in field of renewable energy and sustainable construction.

Through above literatures, there are researches concluded on the feasibility of biomass in generating electricity but there is lacking of study of catalyzing biomass in concrete to generate electricity, and still provide promising concrete properties. It is believe that the potential usage of lignocellulosic biomass in concrete needs to fully explore. Researches [30]-[33] have been carried out at INTI International University to investigate the feasibility of incorporate variety of lignocellulosic biomasses and active catalysts in concrete to generate electricity and at the same time, retain the good properties of concrete. The results show that such concrete mix combination is feasible to generate electricity with a firm external circuit. An average voltage density of $120 \mathrm{~V} / \mathrm{m}^{2}$ is recorded. Such incorporation of lignocellulosic biomass and activated catalyst in concrete has proven able to generate electricity, resulting in more environmental benefits which may bring the construction industry one step ahead others. However, the compressive strength for cube was decreased up to $70 \%$ compared to control specimens [34]. Such degradation may due to oxidation of lignocellulosic biomass with activated catalyst for charges, hence depleting the amount of biomass in producing cementitious materials. With such compressive strength, the application of such invention is only for non-load bearing element, such as wall plaster, wall mansory and etc. Such invention has been filed and patented under patent id PI2018003068. Further investigation is needed to figure out the best mix materials in order to achieve sufficient compressive strength for structural use, and at the same time, generate sufficient charges for electricity.

In this paper, an innovative and promising mixing proportion and materials of Catalyzed Lignocelullosic Biomass Thermoelectric Concrete (CBC), through integrating activated catalyst and activation solution in lignocellulosic biomass concrete, is proposed. The experimental rig of the proposed thermoelectric concrete 
is established in INTI International University, Negeri Sembilan, Malaysia. Basic experimental data for concrete such as compressive strength, density and workability is measured to support the hypothesis. Conductivity test on such concrete was done based on three exposing conditions: cold condition, normal condition and hot condition, covering from $0^{\circ} \mathrm{C}$ to $100^{\circ} \mathrm{C}$. Based on the experimental rig, the best mix proportion with the best power density enhancement ratio is proposed and discussed in detail.

\section{Experimental Work}

\section{Materials, Proportion and Specimen Preparation}

Four series of $\mathrm{CBC}$ cubes for compressive strength test and specimens for conductivity test with dimension $150 \mathrm{~mm} \times 150 \mathrm{~mm} \times 150 \mathrm{~mm}$ and $50 \mathrm{~mm} \times 50 \mathrm{~mm} \times 20 \mathrm{~mm}$, respectively, had been prepared according to mix proportion presented in Table 1 . The testing parameter primarily dealt with incorporation of activation solution with various types of activators, i.e. sodium hydroxide, iron (III) sulfate, and copper (II) sulfate, mixed with prescribed $\mathrm{CBC}$ constituents.
As there are no code provisions for the mix design of $\mathrm{CBC}$, the density of $\mathrm{CBC}$ was assumed as $2400 \mathrm{~kg} / \mathrm{m}^{3}$. DoE design method for M30 concrete was adopted in this study. To maintain fair comparison, activation solution, mixture of sodium silicate and activators, were set fixed at ratio of $40 \%$ to POFA binder. Activators are maintained at 10 Molarity, with molecular weight for sodium hydroxide, Iron (III) sulfate and Copper (II) sulfate of $40 \mathrm{~g} / \mathrm{mol}$, $400 \mathrm{~g} / \mathrm{mol}$ and $160 \mathrm{~g} / \mathrm{mol}$, respectively. The ratio of activators to sodium silicate is kept at 2.5 as recommended by Krishnan et al. [35]. The conventional method used in the making of normal concrete is adopted to prepare $\mathrm{CBC}$. The catalyst and activation solution are added slowly and evenly during mixing process. Right after wet mix was poured and trowelled in mould, CBC cubes and specimens were put in oven for 24 hours heat curing at $90^{\circ} \mathrm{C}$. This aim is to escalate the hydration and pozzolanic processes, as well as to liquefy the catalyst if a powdered form catalyst is used.

It is unrevealed that catalyst in $\mathrm{CBC}$ acts as photochemical and thermochemical catalyst which eventually roles as oxidation agent to oxidize biomass and a charge carrier to receive electrons in catalysed POFA under thermal different. Then deliver the charges to pre-installed circuit and captured by a multimeter.

Table 1. Mix proportion for $\mathrm{CBC}$ with activator solutions

\begin{tabular}{|c|c|c|c|c|}
\hline $\begin{array}{c}\text { Mix } \\
\text { Proportion }\left(\mathrm{kg} / \mathrm{m}^{3}\right) \\
\end{array}$ & $\begin{array}{c}\text { Series } 1 \\
\text { CBC-C30-Conc } \\
\end{array}$ & $\begin{array}{c}\text { Series 2 } \\
\text { CBC-C30-NaOH } \\
\end{array}$ & $\begin{array}{c}\text { Series 3 } \\
\text { CBC-C30- } \mathrm{Fe}_{2}\left(\mathrm{So}_{4}\right)_{3} \\
\end{array}$ & $\begin{array}{c}\text { Series } 4 \\
\text { CBC-C30- CuSo } \\
\end{array}$ \\
\hline $\mathrm{OPC}$ & 350 & 350 & 350 & 350 \\
\hline Fine aggregate & 555 & 555 & 555 & 555 \\
\hline Coarse aggregate & 1295 & 1295 & 1295 & 1295 \\
\hline POFA & 70 & 70 & 70 & 70 \\
\hline Catalyst & 140 & 140 & 140 & 140 \\
\hline Activator/POFA & - & $40 \%$ & $40 \%$ & $40 \%$ \\
\hline Sodium silicate & - & 20 & 20 & 20 \\
\hline Sodium hydroxide & - & 8 & - & - \\
\hline Iron (III) sulfate & - & - & 8 & - \\
\hline Copper (II) sulfate & - & - & - & 8 \\
\hline
\end{tabular}




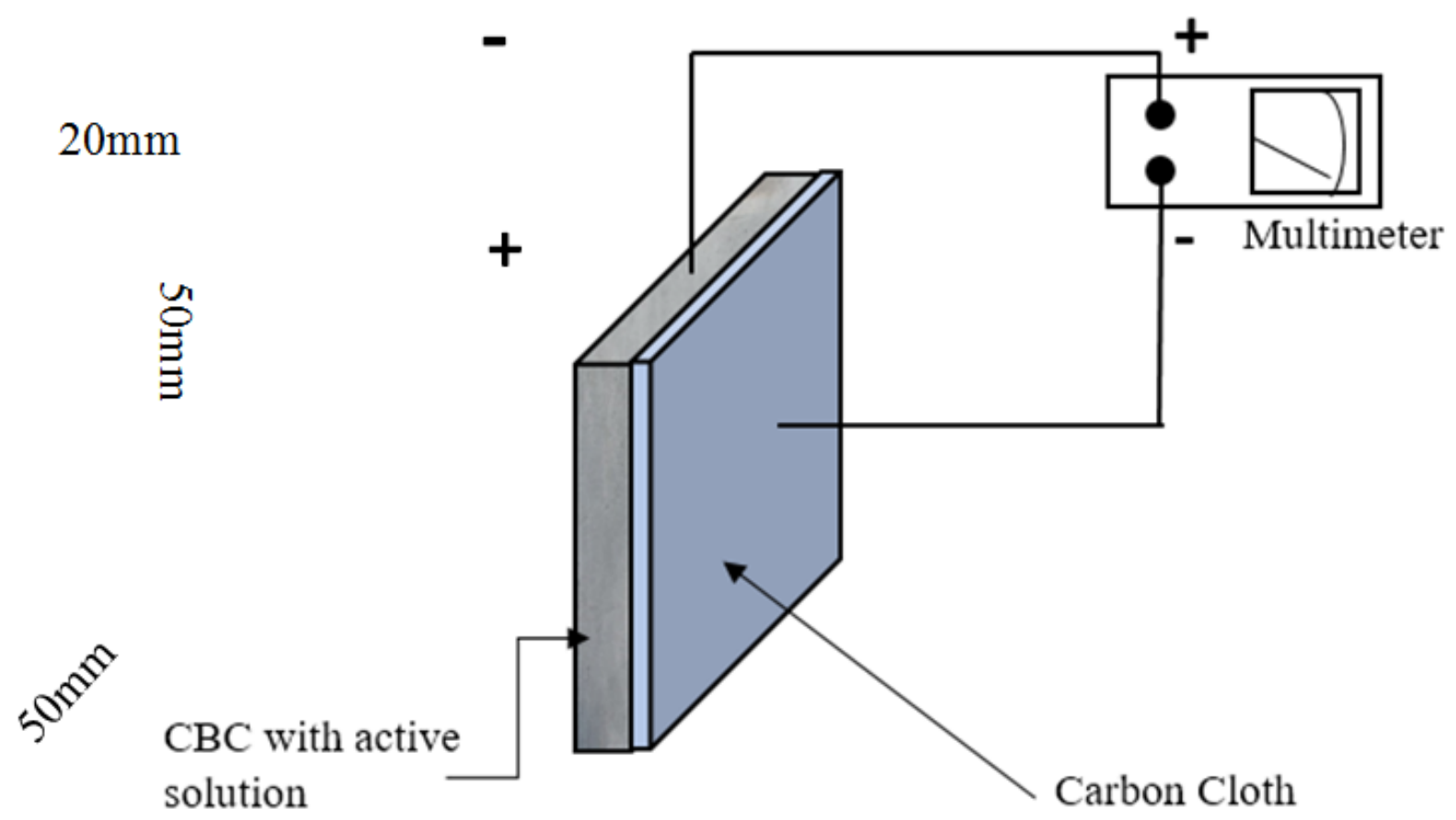

Figure 1. External circuit setup for $\mathrm{CBC}$ with active solution

\subsection{Setup for External Circuit}

Figure 1 illustrates the configuration of the external circuit for $\mathrm{CBC}$ to extract charges generated under thermal different. External circuit can be installed on CBC specimens $(50 \mathrm{~mm} \times 50 \mathrm{~mm} \times 20 \mathrm{~mm})$ after heat curing at $90^{\circ} \mathrm{C}$ for 24 hours if compressive strength is not priority, else prolonged curing is necessary for further hydration and pozzolanic process. The main intention of conducting heat curing is to escalate the cementitious process, and at the same time liquified the catalyst if it is in powder form for a better composite mixture. In the circuit, carbon fibre cloth acts as cathode while $\mathrm{CBC}$ acts as anode where oxidation in constituents occurs. Charges generated by the reaction under thermal exposure will be extracted through the circuit setup from anode to cathode. The amount of charges can be measured by using multi-meter, in voltage format, by referring to existing research on microbial fuel cell [11], [13]. It is necessary to make sure the probes are attached firmly on both anode and cathode. Loose probes and uneven surface on contact point may affect the efficiency of the extraction.

\subsection{Setup for Conductivity Test}

$\mathrm{CBC}$ with complete circuit generates charges when exposed to thermal different, to examine its efficiency under different exposing environment and temperature, CBC conductivity test is designed in this study due to lacking of relevant standard of practise. To limit the exposing temperature to human-acceptable level, exposing temperature is categorised to cold condition, normal condition and hot condition. Cold condition covers exposing temperature from $0^{\circ} \mathrm{C}$ to $20^{\circ} \mathrm{C}$, normal condition from $20^{\circ} \mathrm{C}$ to $60^{\circ} \mathrm{C}$, while hot condition is up to $100^{\circ} \mathrm{C}$. Cold condition can be achieved by placing specimen in refrigerator or covering it with ice, while normal and hot condition can be done by putting specimen under room temperature, oven or in boiling water. When exposing temperature reaches the desired temperature, multimeter probes are then connected steadily onto cathode and anode. It is important to make sure $\mathrm{CBC}$ is always in dry condition so to maintain the validity of the data, the voltage value will boost up drastically if it is contacted with liquid or any acidic/alkaline solution. The voltage reading is only to be recorded after voltage fluctuation on probes connection is stabilised. Repeat the measurements for 10 times per specimen so to achieve results with good confident level. Figure 2 (a), (b) and (c) show the conductivity test for $\mathrm{CBC}$ with complete circuit under cold, normal and hot condition respectively.

\subsection{Compressive Load Test}

Existing studies in INTI International University, Malaysia [30]-[34] reported a drastic degradation in compressive strength compared to targeted mean strength was observed when conventional concrete mixed with unrevealed catalyst only. Degradation in strengths more than $60 \%$ compared to control specimens was recorded. It may due to the oxidation of biomass leads to strength reduction, as the oxidized biomass is used to carry charges for electric generation. Thus, activators (listed in Table 1), are believe can enhance the compressive strength of concrete by its geopolymerization process [36]. 


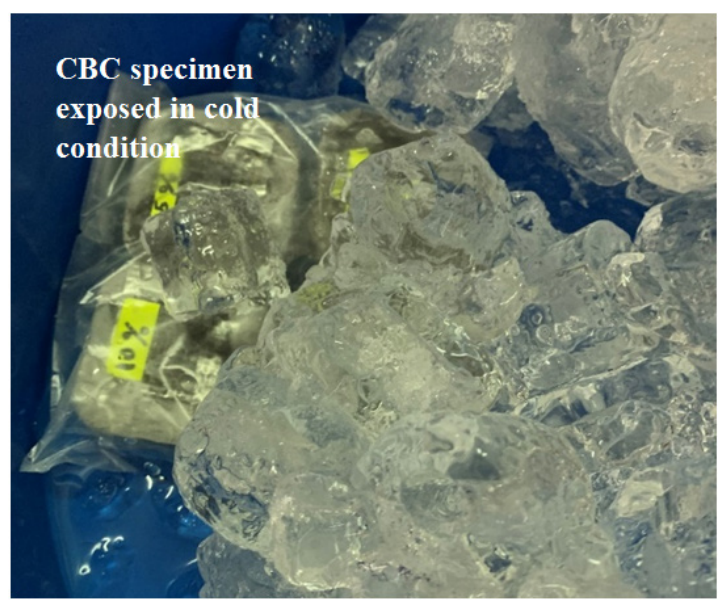

(a)

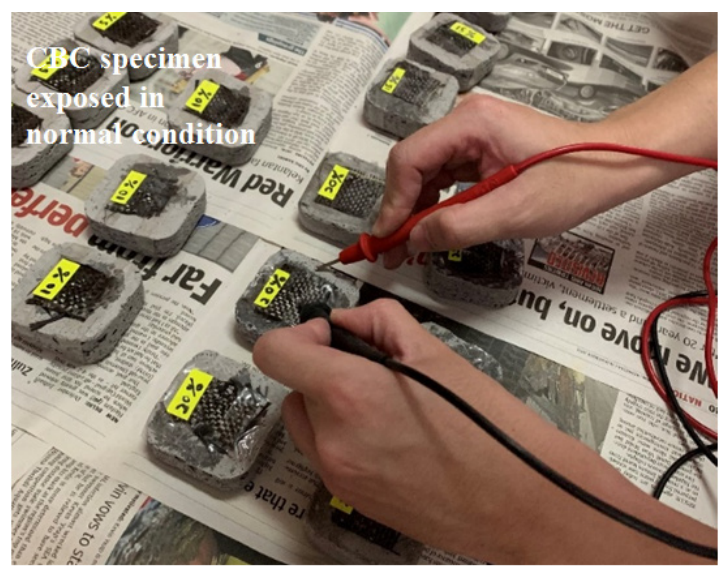

(b)

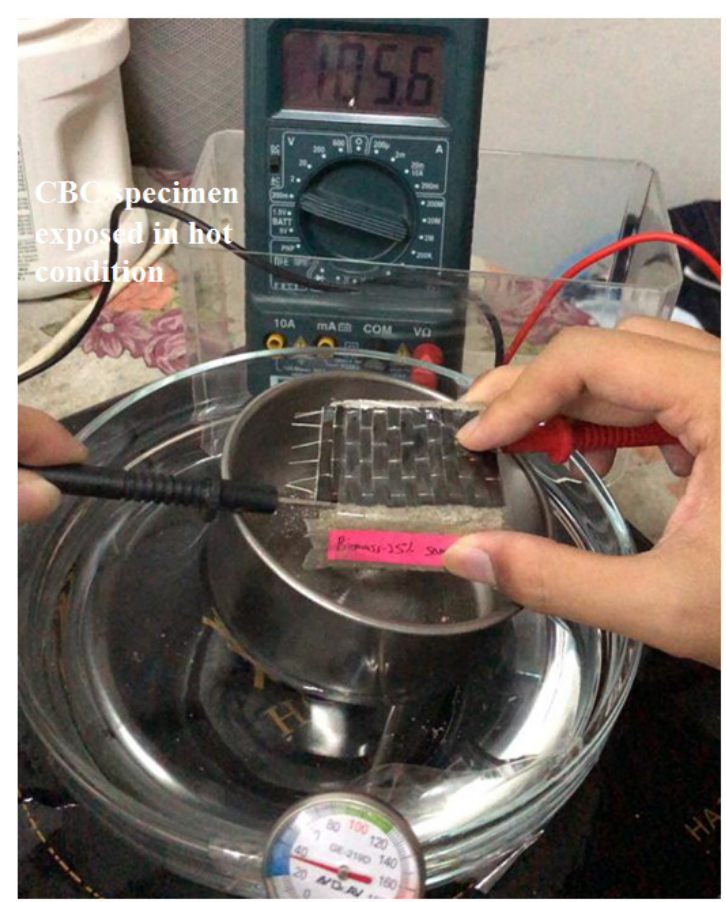

(c)

Figure 2. Conductivity test for (a) cold condition, (b) normal condition and (c) hot condition
To compute compressive strength of $\mathrm{CBC}$ in this study, its cube specimen was uniaxially compressed. The compressive strength tests done were compliance with ASTM C39/C39M [37]. Specimens were loaded until failure right after water curing (compliance to ASTM C192 [38]) for $7^{\text {th }}, 28^{\text {th }}$, and $56^{\text {th }}$ day. Concrete density was recorded for each cube before test, cracking and failure behaviour was observed during test, ultimate compressive strength value was recorded when cube reached peak capacity.

\section{Test Results}

\subsection{Slump Test}

Slump test was conducted based on ASTM C143/C143M [39] to observe the workability of fresh CBC mixed with activation solutions. The slump results are tabulated in Table 2. Targeted slump was designed with range $30 \mathrm{~mm}$ to $60 \mathrm{~mm}$ according to DoE. It was noted that the consistency of $\mathrm{CBC}$ with activation solution was not affected and showed slump losses within the designed range, except for $\mathrm{CBC}-\mathrm{C} 30-\mathrm{NaOH}$. In this case, the slump value was found to be below the acceptable range, i.e. $20 \mathrm{~mm}$. These phenomena are reported normal for alkali activation solution due to slower dissolution in the solution, hence providing a lower slump value [40]. It can be observed that all fresh CBC mixes were workable after the addition of activation solution and were easily compacted into the moulds.

Table 2. Slump test results for $\mathrm{CBC}$ with activation solutions

\begin{tabular}{|c|c|}
\hline Specimen sets & Slump result (mm) \\
\hline $\mathrm{CBC}-\mathrm{C} 30-\mathrm{Conc}$ & 32 \\
\hline $\mathrm{CBC}-\mathrm{C} 30-\mathrm{NaOH}$ & 20 \\
\hline $\mathrm{CBC}-\mathrm{C} 30-\mathrm{Fe}_{2}\left(\mathrm{So}_{4}\right)_{3}$ & 31 \\
\hline $\mathrm{CBC}-\mathrm{C} 30-\mathrm{CuSO}_{4}$ & 33 \\
\hline
\end{tabular}

\subsection{Compression Test}

Before compressive testing, all cubes were weighted and the average density of each series of cubes is presented in Figure 3. It is noted that on average, all cubes are having density near to $2400 \mathrm{~kg} / \mathrm{m}^{3}$, the highest and lowest density obtained are $2343 \mathrm{~kg} / \mathrm{m}^{3}$ and $2154 \mathrm{~kg} / \mathrm{m}^{3}$ with standard deviation of $52 \mathrm{~kg} / \mathrm{m}^{3}$, average density of $2262 \mathrm{~kg} / \mathrm{m}^{3}$. The average density has acceptable deviation of $5.74 \%$ compared to the pre-determined density used in DoE mix proportion design. Hence, it can be noted that density has minor effect on the compressive strength of $\mathrm{CBC}$ with activation solution, which can be ignored as large disparity in density affecting the compressive strength of concrete [41]. With that, it is proven that CBC concrete is prepared with good consistency and 
workmanship, and the research study was carried out in a comparative comparison manner.

CBC cubes were tested in compressive testing machine ( $1500 \mathrm{kN}$ capacity) to obtain their compressive strength at the age of 7 day, 28 days and 56 days of curing. The graph of average compressive strength result is presented in Figure 4. It was found that as the curing age of the CBC with different activation solutions increases, the compressive strength is enhanced with different rates. With addition of catalyst in concrete mix, control cubes showed degradation of $32.56 \%$ to targeted mean strength right after 56 days of curing. Such degradation is reported normal due to catalyzation between the catalyst and biomass to charges [30]-[33]. The results have shown that the CBC with Iron (III) sulfate gave maximum strength compare to the rest, with strength enhancement ratio of 1.42. While strength enhancement ratio for $\mathrm{CBC}$ with sodium hydroxide and copper (II) sulfate are great below compared to control specimen, i.e. 0.69 and 0.77 , respectively. Other than Iron (III) sulfate, the rest of activation solution does not give enhancement effect to CBC.

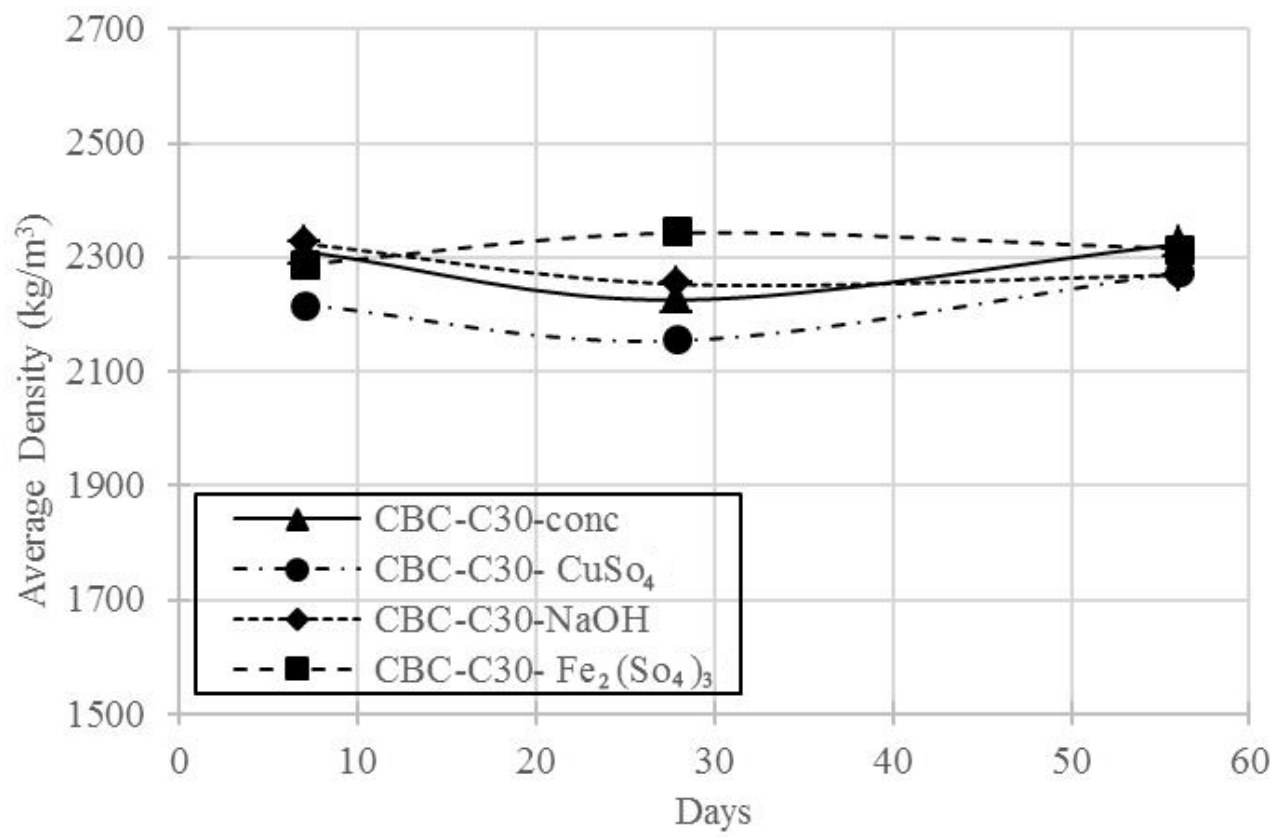

Figure 3. The average density of $\mathrm{CBC}$ cubes with various activation solutions

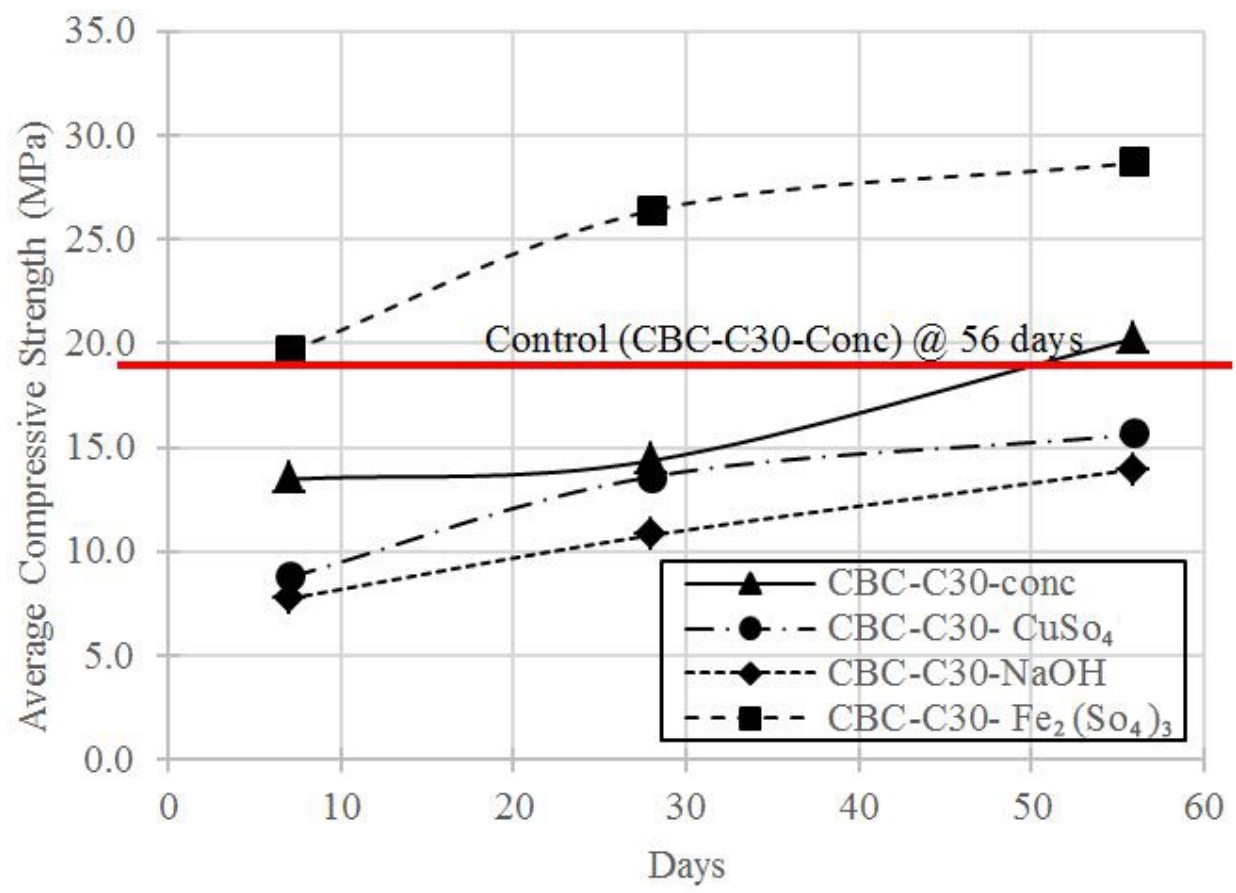

Figure 4. Average compressive strength of $\mathrm{CBC}$ cubes with various activation solution 


\subsection{Conductivity Test}

Figure 5 illustrates the graph of power density versus exposing temperature for $\mathrm{CBC}$ with different activation solutions. Exposed temperature ranging from $0^{\circ} \mathrm{C}$ to $100^{\circ} \mathrm{C}$ was examined on all $\mathrm{CBC}$ sets in an interval of $10^{\circ} \mathrm{C}$. Overall, it can be observed that the power density is directly proportional to exposed temperature from $0^{\circ} \mathrm{C}$ to $100^{\circ} \mathrm{C}$. CBC with copper (II) sulfate possesses the highest in power density generation amongst the others, while control sample generated lowest power density. This is due to such mix contains conducting material, i.e. copper and hence boosting up the voltage generation. $\mathrm{CBC}$ with sodium hydroxide and iron (III) sulfate is having near to identical power density generation. The rate of increment in power density is almost steady and consistent to the increment in exposed temperature. It can be clearly observed in Figure 6, where near to constant power density ratios are obtained from $10^{\circ} \mathrm{C}$ to $100^{\circ} \mathrm{C}$. High-density ratio is observed at $0^{\circ} \mathrm{C}$ due to voltage unstable for control sample, and this phenomenon can be ignored. With increase in exposed temperature, the power density for CBC with copper (II) sulfate increases steadily at average ratio of 2.08 compared to control specimen, where $\mathrm{CBC}$ with sodium hydroxide and iron (III) sulfate increases steadily at average ratio of 1.14 and 1.05 respectively. The waveform of electrical signal of $\mathrm{CBC}$ with various activation solutions has been analysed using Oscilloscope as shown in Figure 7. Although the generated voltage is low, it gives stable pulsating direct current. With proper amplifier circuit, it will boost up the voltage and hence suitable for further application. However, it is to be noted that setting up amplifier circuit is not the main objective of the study hence it is not discussed in this paper. In a nutshell, it can be concluded that with additional of activation solution, it is able to boost up the power density and compressive strength of CBC. Various activation solutions give different increasing density ratios.

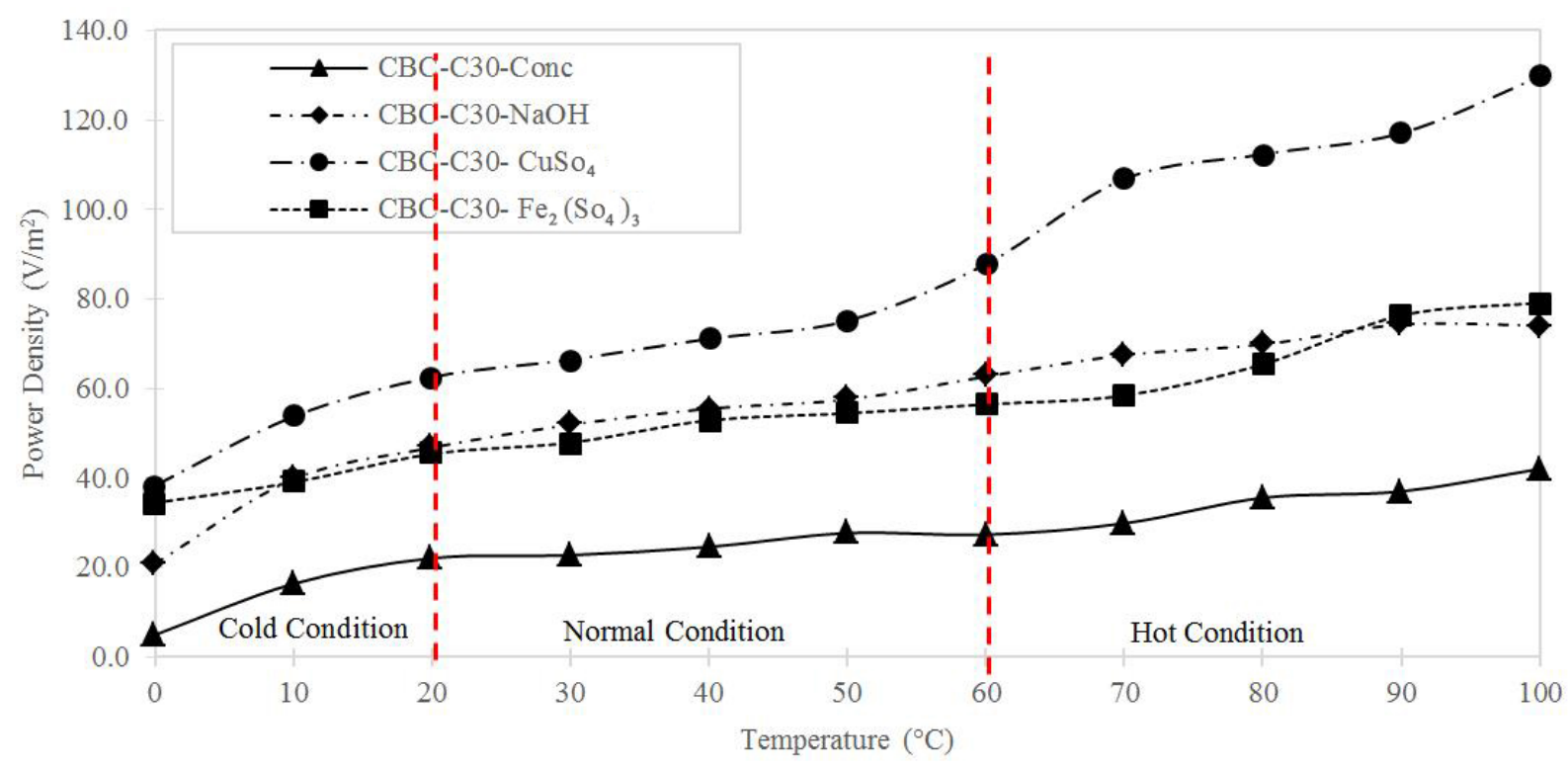

Figure 5. Graph of power density versus exposed temperature for $\mathrm{CBC}$ with different activation solutions 


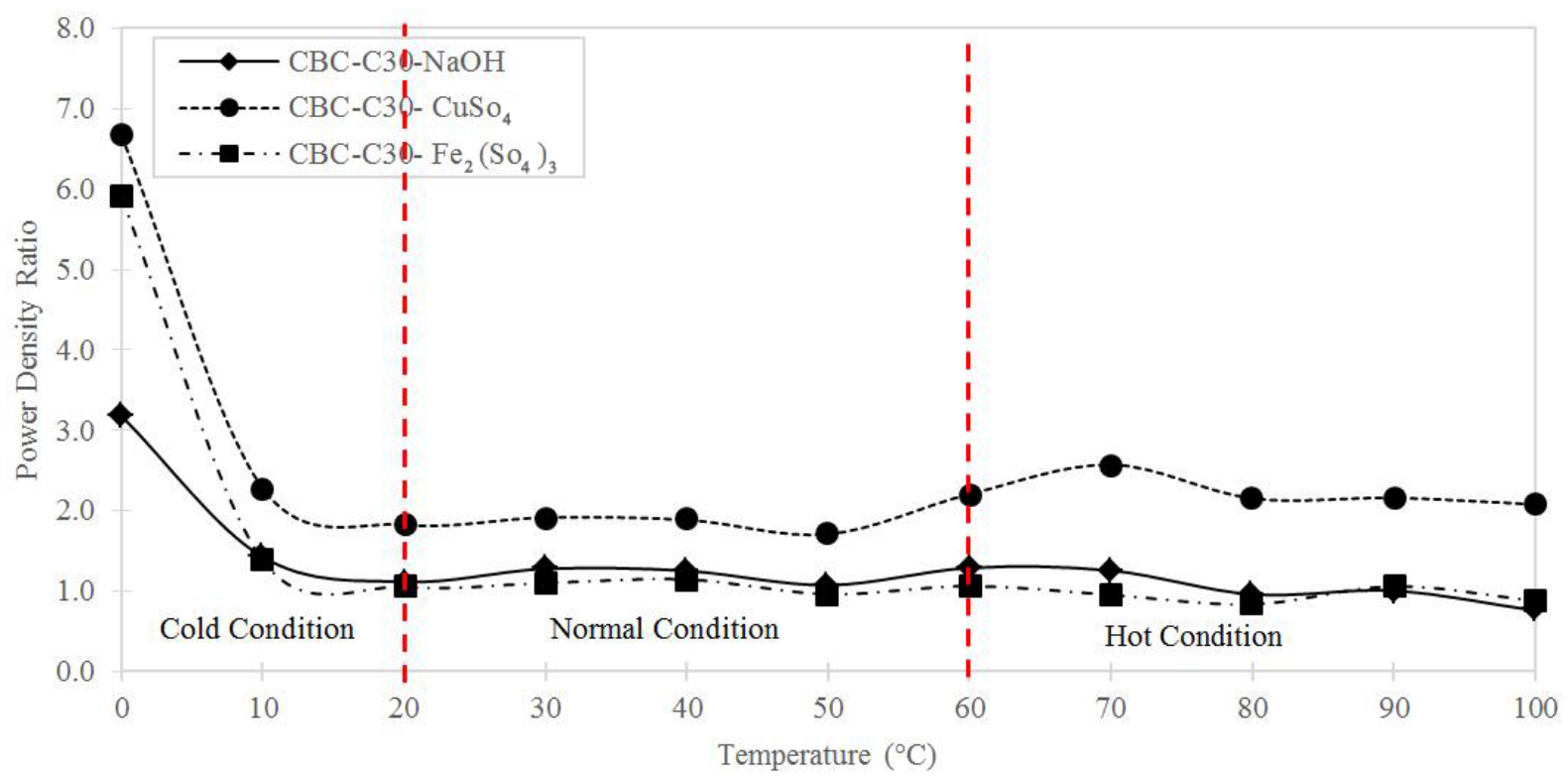

Figure 6. Graph of power density ratio versus exposed temperature for $\mathrm{CBC}$ with different activation solutions.

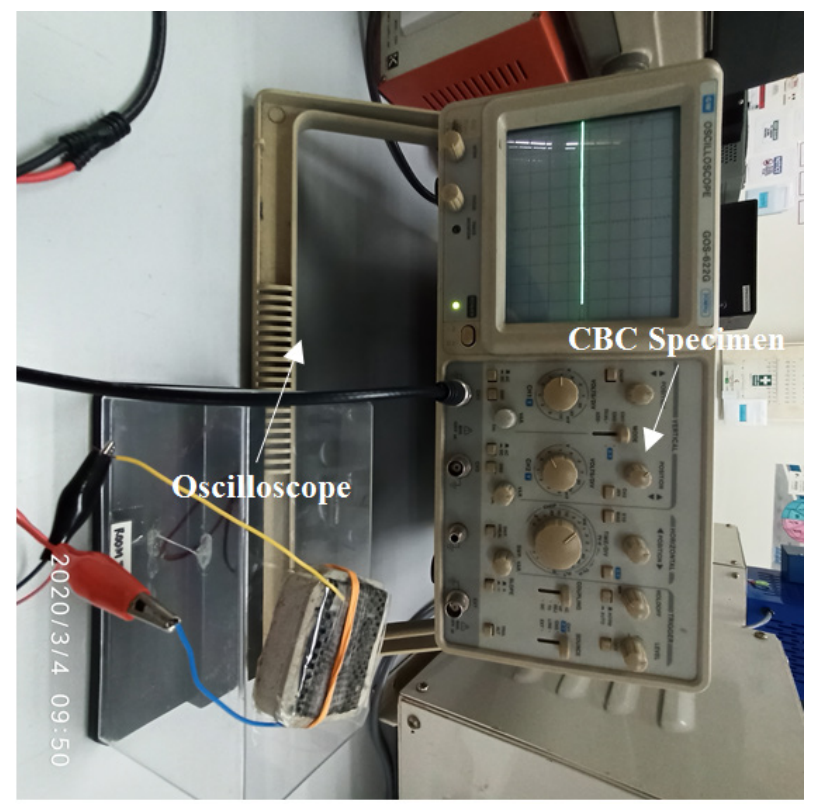

Figure 7. Verifying the pulsating of $\mathrm{CBC}$ with Oscilloscope

\section{Conclusions}

In this experimental study, a total of four series of activation solutions including control was mixed with $\mathrm{CBC}$, i.e. sodium silicate with activators such as sodium hydroxide, iron (III) sulfate and copper (II) sulfate. The mixtures were tested and evaluated under workability test, uniaxial compressive strength test, and conductivity test. Based on the test results, several conclusions have been drawn:
1. Other than sodium hydroxide, addition of activation solutions in CBC will not affect the workability of the fresh mix. Activation solution mix of sodium silicate and sodium hydroxide pertains high cohesiveness and as a result, lowering the workability of the fresh mix compared to estimated slump.

2. Compressive strength of $\mathrm{CBC}$ with iron (III) sulfate as activation solution is recorded achieving the highest amongst the rest, with an enhancement ratio of 1.42 compared to control specimens after moist curing for 56 days. An average compressive strength of $28.66 \mathrm{MPa}$ is recorded, showing the feasibility of $\mathrm{CBC}$ to be used as structural elements and at the same time, a renewable energy collector in construction industry. While for $\mathrm{CBC}$ with sodium hydroxide and copper (II) sulfate, the compressive strength enhancement ratio is 0.69 and 0.77 after moist curing for 56 days. Further study on mix design and strength development especially for $\mathrm{CBC}$ with copper (II) sulfate is needed as it able to generate highest voltage density among others.

3. $\mathrm{CBC}$ with activation solutions is able to generate stable direct voltage. However, the voltage per sample is relatively small and a booster circuit is needed for further application.

4. The experimental study shows that $\mathrm{CBC}$ with copper (II) sulfate is able to produce more power density compared to the rest of activation solutions. An average increment rate of 2.08 per $10^{\circ} \mathrm{C}$ is recorded when the specimens were exposed to temperature ranged from $10^{\circ} \mathrm{C}$ to $100^{\circ} \mathrm{C}$, regardless or cold, normal or hot condition. Average power density increment rate of 1.14 and 1.05 were recorded for 
CBC with sodium hydroxide and iron (III) sulfate, respectively.

\section{Acknowledgments}

The research described in this paper is supported by the FRGS 2020-1 under Vot FRGS/1/2020/TK0/INTI/02/1. Laboratory testing of the specimens were performed in the Concrete Laboratory, INTI International University, Nilai. Assistance from the dutiful technicians was very much acknowledged.

\section{REFERENCES}

[1] T. Ma, P. Østergaard, H. Lund, H. Yang, and L. Lu, "An energy system model for Hong Kong in 2020," Energy, vol. 68, pp. 301-310, 2014.

[2] Y. Luo, Z. Ling, Z. Liu, Y. Wang, F. Meng, and W. Jing, "Thermal performance evaluation of an active building integrated photovoltaic thermoelectric wall system," Appl Energy, vol. 177, pp. 25-39, 2016.

[3] H. M. Hamada, G. A. Jokhio, F. M. Yahaya, and A. M. Humada, "The present state of the use of palm oil fuel ash (POFA) in concrete," Constr. Build. Mater., vol. 175, pp. 26-40, 2018.

[4] R. A. Armin, A. Sumper, and A. Davarpanah, "Development of sustainable energy indexes by the utilization of new indicators: A comparative study," Energy Reports, vol. 5, pp. 375-383, 2019.

[5] M. Salvo et al., "Biomass ash as supplementary cementitious material (SCM)," Adv. Appl. Ceram., vol. 114, pp. 3-10, 2015.

[6] P. Bajpai, Biomass to Energy Conversion Technologies. Elsevier, 2020.

[7] A. Tursi, "A review on biomass: Importance, chemistry, classification, and conversion," Biofuel Res. J., vol. 6, no. 2, pp. 962-979, 2019.

[8] W. Wu, W. Liu, W. Mu, and Y. Deng, "Polyoxymetalate liquid-catalyzed polyol fuel cell and the related photoelectrochemical reaction mechanism study," J. Power Sources, vol. 318, pp. 86-92, 2016, doi: 10.1016/j.jpowsour.2016.03.074

[9] Georgia Institute of Technology, "Hybrid fuel cell produces electricity directly from biomass," Phys Org, no. February, pp. 1-5, 2014.

[10] V. Kumari Sapra, "A Newer Approach To Green Earth Solar-Induced Hybrid Biomass Fuel Cell," Am. Int. J. Res. Formal, Appl. Nat. Sci., vol. 14, no. 278, pp. 141-142, 2014.

[11] W. Liu, W. Mu, M. Liu, X. Zhang, H. Cai, and Y. Deng, "Solar-induced direct biomass-to-electricity hybrid fuel cell using polyoxometalates as photocatalyst and charge carrier," Nat. Commun., vol. 5, p. 3208, 2014, doi:
$10.1038 /$ ncomms 4208 .

[12] X. Zhao, W. Liu, Y. Deng, and J. Zhu, "Lignocellulosic Biomass-Energized Fuel Cells: cases of High-Temperature Conversion," Momentum Press, 2015.

[13] W. Liu, W. Mu, M. Liu, X. Zhang, H. Cai, and Y. Deng, "Solar-induced direct biomass-to-electricity hybrid fuel cell using polyoxometalates as photocatalyst and charge carrier," Nat. Commun., vol. 5, no. February, p. 3208, 2014, doi: $10.1038 /$ ncomms4208.

[14] X. Zhao, W. Liu, Y. Deng, and J. Y. Zhu, "Low-temperature microbial and direct conversion of lignocellulosic biomass to electricity: Advances and challenges," Renew. Sustain. Energy Rev., vol. 71, no. October 2015, pp. 268-282, 2017, doi: 10.1016/j.rser.2016.12.055.

[15] W. Liu, C. Liu, P. Gogoi, and Y. Deng, "Overview of Biomass Conversion to Electricity and Hydrogen and Recent Developments in Low-Temperature Electrochemical Approaches," Engineering, vol. 6, no. 12, pp. 1351-1363, 2020, doi: 10.1016/j.eng.2020.02.021.

[16] A. Evans, V. Strezov, and T. J. Evans, "Sustainability considerations for electricity generation from biomass," Renew. Sustain. Energy Rev., vol. 14, no. 5, pp. 33-52, 2014, doi: 10.1201/b17093.

[17] M. M. Ul-Islam, K. H. Mo, U. J. Alengaram, and M. Z. Jumaat, "Durability properties of sustainable concrete containing high volume palm oil waste materials," J. Clean. Prod., vol. 137, pp. 167-177, 2016.

[18] M. Velay-Lizancos, M. Azenha, I. Martínez-Lage, and P. Vázquez-Burgo, "Addition of biomass ash in concrete: Effects on E-Modulus, electrical conductivity at early ages and their correlation," Constr. Build. Mater., vol. 157, pp 1126-1132, 2017.

[19] M. H. Warid and M. Khairunisa, "Properties of Palm Oil Fuel Ash Cement Based Aerated Concrete Panel Subjected To Different Curing Regimes," Malaysian J. Civ. Eng., vol. 21, no. 1, pp. 17-30, 2009.

[20] T. Z. H. Timothy, T. Z. Y. Matthew, R. E. Muhammad, and P. Vikram, "Palm Oil Fuel Ash: Innovative Potential Applications as Sustainable Materials in Concrete," in Reference Module in Materials Science and Materials Engineering, 2019.

[21] P. Chindaprasirt, S. Rukzon, and V. Sirivivatnanon, "Resistance to chloride penetra-tion of blended Portland cement mortar containing palm oil fuel ash, rice husk ash and fly ash," Constr. Build. Mater., vol. 22, no. 5, pp. 932938, 2008.

[22] P. Chindaprasirt, S. Homwuttiwong, and C. Jaturapitakkul, "Strength and water per-meability of concrete containing palm oil fuel ash and rice husk-bark ash," Constr. Build. Mater., vol. 21, no. 7, pp. 1492-1499, 2007.

[23] T. Weerachart and C. Jaturapitakkul, "Strength, drying shrinkage, and water permeability of concrete incorporating ground palm oil fuel ash," Composites, vol. 32, no. 10, pp. 767-774, 2010

[24] C. Jaturapitakkul, K. Kraiwood, T. Weerachart, and S. Tirasit, "Evaluation of the sulfate resistance of concrete 
containing palm oil fuel ash," Constr. Build. Mater., vol. 21, no. 7, pp. 1399-1405, 2007.

[25] M. A. Megat Johari, A. M. Zeyad, N. Muhamad Bunnori, and K. S. Ariffin, "Engineering and transport properties of high-strength green concrete containing high volume of ultrafine palm oil fuel ash," Constr. Build. Mater., vol. 30, pp. 281-288, 2012, doi:

10.1016/j.conbuildmat.2011.12.007.

[26] B. S. Thomas, S. Kumar, and H. S. Arel, "Sustainable concrete containing palm oil fuel ash as a supplementary cementitious material - A review," Renew. Sustain. Energy Rev., vol. 80, no. July 2016, pp. 550-561, 2017, doi: 10.1016/j.rser.2017.05.128.

[27] E. Aprianti, P. Shafigh, B. Syamsul, and J. Nodeh Farahani, "Supplementary cementitious materials origin from agricultural wastes - A review," Constr. Build. Mater., vol. 74, pp. 176-187, 2015.

[28] P. K. Das, B. P. Das, and P. Dash, "Potentials of postharvest rice crop residues as a source of biofuel," Refin. Biomass Residues Sustain. Energy Bioprod. Technol. Adv. Life Cycle Assessment, Econ., vol. 2014, pp. 275-301, 2019, doi: 10.1016/B978-0-12-818996-2.00013-2.

[29] K. Merklein, S. S. Fong, and Y. Deng, Biomass Utilization. Elsevier B.V., 2016.

[30] C. Wan-Foong and L. Hoong-Pin, "Catalyst Biomass Concrete Using Palm Oil Fuel Ash (POFA),” 2019.

[31] P. Zhen-Xiang and L. Hoong Pin, "The Effect of Catalyst Biomass Concrete with Sawdust Ash on Different Content of Activated Catalyst," INTI INTERNATIONAL UNIVERSITY, 2019.

[32] G. Chee-King and L. Hoong-Pin, "The Effect of Biomass in Generating Electricity for Catalyst Biomass Concrete," INTI INTERNATIONAL UNIVERSITY, 2019.
[33] K.-S. Lim and H.-P. Lee, "Different Type of Biomass Material Uses in Concrete Essential for Generating Electricity," INTI INTERNATIONAL UNIVERSITY, 2019.

[34] H.-P. Lee, W. Chak, K. Teow, W. Lee, B. A. Rahman, and A. Z. Awang, "Investigation of Catalysed Biomass Thermoelectric Concrete with Palm Oil Fuel Ash," in International Conference on Sustainable Civil Engineering Structures and Construction Materials (SCESCM2020), 2020, pp. 1-13.

[35] L. K., "Geopolymer Concrete an Eco-Friendly Construction Material," Int. J. Res. Eng. Technol., vol. 03, no. 23, pp. 164-167, 2014, doi: 10.15623/ijret.2014.0323036.

[36] C. K. Ma, A. Z. Awang, and W. Omar, "Structural and material performance of geopolymer concrete: A review," Constr. Build. Mater., vol. 186, pp. 90-102, 2018, doi: 10.1016/j.conbuildmat.2018.07.111.

[37] ASTM C 39/C39M, "Standard test method for compressive strength of cylindrical concrete specimens," ASTM Int. West Conshohocken, 2011.

[38] ASTM C192/C192M, "Standard Practice for Making and Curing Concrete Test Specimens in the Laboratory," ASTM Int. West Conshohocken, 2014.

[39] ASTM C143/C143M, "Standard test method for slump of hydrauliccement concrete," Annual Book of ASTM Standards. 2002.

[40] K. Srinivasan and A. Sivakumar, "Chemical activation and curing regime of geopolymer concretes," Proc. Inst. Civ. Eng. Constr. Mater., vol. 168, no. 1, pp. 24-34, 2015, doi: 10.1680/coma.13.00024.

[41] S. Iffat, "Relation between density and compressive strength of hardened Concrete," Concr. Res. Lett., vol. 6, no. 4, 2015, doi: 10.3390/ma14112967. 